\title{
Comparison of the University Students in Turkey and Central Asia with Regards to Their Characteristics of Thinking, Decision Making and Cognitive Closure
}

\author{
Hasan Yilmaz ${ }^{1}$ \\ 'Kyrgyz-Turkish Manas University, Faculty of Literature, Department of Educational Sciences, Kyrgyzstan \\ Email: hasan.yilmaz@manas.edu.ig. Tel: +996706451051
}

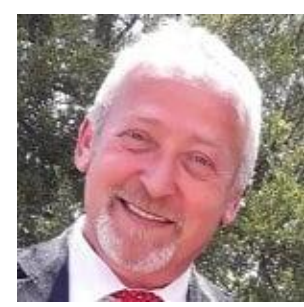

\begin{abstract}
The aim of this study is to compare the Turkish, Uzbek and Kyrgyz university students with regards to their thinking and decision making styles and as well as their cognitive closure. 141 Turkish, 69 Uzbek and 89 Kyrgyz students at the Kyrgyz-Turkish Manas University participated in the study. As the data collection tool, the 15-point version of the thinking styles scale, decision making styles scale and the need for cognitive closure scale were used. The data were examined with the one-way variance analysis and the T2 test of Scheffe and Tamhane was applied to find the source of the difference in groups where a difference was determined. As a result of the study, significant differences were found between the Turkish, Uzbek and Kyrgyz students in 11 of the 13 thinking styles and in 3 of the 5 decision making styles. The highest difference in 3 sample groups was found for the need for cognitive closure. The importance of knowing the thinking and decision making styles of different cultures as a prerequisite for intercultural communication and cooperation was highlighted and some recommendations were made on this matter.
\end{abstract}

Keywords: Thinking styles, Decision making styles, Need for cognitive closure.

Citation | Hasan Yllmaz (2018). Comparison of the University Students in Turkey and Central Asia with Regards to Their Characteristics of Thinking, Decision Making and Cognitive Closure. Asian Journal of Education and Training, 4(4): 309-318.

History:

Received: 4. July 2018

Revised: 11 August 2018

Accepted: 30 August 2018

Published: 14 September 2018

Licensed: This work is licensed under a Creative Commons

Attribution 3.0 License (cc)

Publisher: Asian Online Journal Publishing Group
Funding: This study received no specific financial support

Competing Interests: The author declares that there are no conflicts of interests regarding the publication of this paper.

Transparency: The author confirms that the manuscript is an honest, accurate, and transparent account of the study was reported; that no vital study as planned have been explained.

Ethical: This study follows all ethical practices during writing.

\section{Contents}

1. Introduction

4. Discussion.

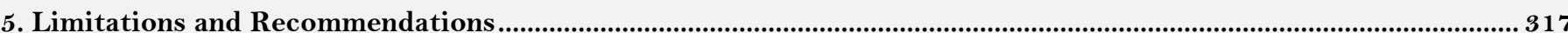

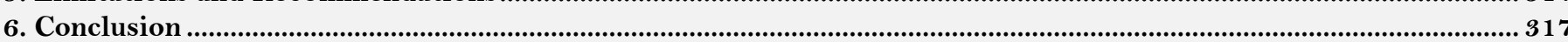

References. 


\section{Introduction}

Two basic distinct features and obligation of being a human are thinking and decision making. Either aware or unaware, we think and make decision in every moments of our lives. These decisions may be related to the clothes to put on, the person to marry, the profession or the person to rule a country. Shortly, everything we have and the position we are in right now is the result of the decisions we make. The feature of decision making is directly related to the thinking competence. In other words, we are able to make decisions as we are able to think. In this respect, these two features are both interrelated and interdependent.

Not all thinking ways are healthy, functional and purposeful. The same is valid for the decision making styles. There are many variables affecting thinking and decision making. For a general classification, we can group theses variables to the factors that are related or not related to an individual. Individual variables mainly involve our cognitive structure and personal qualities while the most important environmental variables are the social structure and culture that we live and are raised in. Our thinking and decision making styles are shaped by the interaction of these two general structures. Therefore, we can talk about individual differences as well as cultural differences regarding the thinking and decision making styles.

The cultural differences regarding the thinking and decision making styles are a factor that determines the quality and outcomes of the communication and interaction of people living in different cultures. The importance of communication, interaction, agreement, reconciliation and cooperation between countries is ever increasing today and living together in different cultures makes it necessary for the people to know their thinking and decision making styles of each other. This requirement will play an important role for the reduction and solution of the disputes and conflicts between societies in addition to providing benefits in every fields from business to politics and from education to law.

\subsection{Thinking Styles}

Thinking is defined to be the disciplined way of conceptualization, application, analysis and evaluation of the knowledge obtained through observation, experience, intuition, reasoning and other channels. The thinking style is the preferred way of thinking and it is related to our way of using the skills we have (Sternberg, 2001). Although there are many theories on thinking skills, this study is based on the "Theory of Mental Self-Government" by Sternberg. Recent studies were conducted on the basis of the principles and descriptions of this theory as it is both comprehensive and multidimensional. The theory is based on the principle that every individual has a unique thinking style which can vary by time and according to the life demands. The Theory of Mental Self-Government defines 13 thinking styles under 5 dimensions including functions, forms, levels, scopes and leanings. These styles were described with the concepts of legislative, executive, judicial, hierarchic, oligarchic, monarchic, anarchic, global, local, internal, external, liberal and conservative (Zhang and Huang, 2001).

As the thinking styles are effective in every domains of life, the studies on this subject vary too. Some of the variables which may involve a relation between thinking and decision making styles include coping with stress (Yuan et al., 2017) obesity (Nikčević et al., 2017) living quality (Kim, 2011) career selection (Kim, 2011); (Cheng et al., 2011) communication and learning styles (Liliweri, 2017). There are several studies on the question whether the thinking styles vary by sex. Despite lacking a common result from these studies, it has been observed that the thinking styles are significantly different among men and women in traditional societies while this difference does no longer exist in western societies (Aljojo, 2017); (Sternberg and Cilliers, 2001).

There are many previous studies on the relations between the thinking styles and performance. These studies show that different performances are affected by different thinking styles and there isn't any single thinking style that determines all performance types (Yaakobi, 2017). There are also studies which prove that the thinking styles can change by education (Jun, 2016). A study by Fan et al. (2018) determined that the personality traits explain only a minor part of the thinking styles which are affected significantly by factors other than the personality traits. Several researchers that adopt this view conducted studies including intercultural comparisons on thinking styles. However, most of these studies cover the samples in USA, China and Japan. The differences in these studies on thinking and decision making styles were evaluated within the context of collectivist and individualist culture. It is argued that the American based Western thinking style focuses on individuals and objects and represents the analytical thinking style while the China based Eastern thinking style is holistic and focuses on culture and system (Torrance and Sato, 1979); (Qi, 2017); (Cherian, 2014).

There are also authors with critical approach to the studies on thinking styles. The common idea of these authors is that the subject of thinking styles is mainly addressed by the Western researchers and the measurement tools are developed in western cultures which affect the research results. In recent publications, there is a discussion on that the theoretical information on thinking styles is a product of the Western culture which limits the ability to discover the universal aspect of the human thinking (Lee, 2017); (Varnum et al., 2010).

\subsection{Decision Making Styles}

Decision making is defined to be a mental process where an idea or action is selected among other options (Byrnes, 2002). Within this process, our needs, desires, goals, values and life styles are effective and decisive as well as the recognition and definition of the options. Ever decision making first involves an uncertainty and every decision involves more or less a risk (Lee, 2017).

The concept of "decision making styles" was created to explain the differences and variety in decision making process. The decision making styles are used to explain the basics and method in decision making. In other words, decision making style is defined to be the condition where a person has an approach, reaction and action in a decision making condition (Spicer and Sadler-Smith, 2005). There are various theories explaining the decision making styles. This study adopts the "General Decision Making Style" approach by Scott and Bruce (Scott and Bruce, 1995). For Scott and Bruce, the decision making style is a pattern of habit used by individual in decision making (Scott and Bruce, 1995). These two scientists defined five decision making styles including rational, intuitive, dependant, avoidant and spontaneous and developed the "decision making styles scale" based on these concepts. 
In a study on the students from USA and Taiwan (Mau, 2000) it was found that the style and self-efficacy for decision making on career are affected by culture. The study found that the decision making styles affected the decision making competency of individuals based on their cultural past. A study conducted in Europe 14 years after this one found similar results. In a study within the samples of Croatia, Slovenia, Bosnia Herzegovina and Hungary to determine the effect of national culture on decision making styles (Dabic et al., 2015) it was observed that collectivist approach in decision making was reduced while a tendency towards individualism increased. On the other hand, it was also found that cultural differences had a decisive role on decision making styles. In a study on a sample consisting of German, American, Indian, Philippine and Brazilian individuals (Güss and Dörner, 2011) the decision making styles of the subjects were observed in a simulation. The study found cultural differences in the decision making strategies of the sample group consisting of the Germans, Americans and other countries. This was interpreted such that the cognitive processes of people are in integrity with the cultural structure. Significant differences were found in the decision making styles in a study which compared the decision making styles of the Swedish and German employees within a project group (Müller et al., 2008) and the researchers linked these differences to the personality traits and job attitudes of the individuals.

\subsection{Need for Cognitive Closure}

The need for cognitive closure, a concept introduced by Kruglanski to the literature, is the need to reach a definitive information instead of chaos and uncertainty on a subject and the desire to make a decision as soon as possible. In other words, it is defined to be the need for orienting towards an answer when an individual has a confusion or uncertainty after facing a situation of decision making or a choice. The motive of individuals to simplify complex information and to avoid uncertainty underlies the need for cognitive closure (Kruglanski and Webster, 1996). According to Kruglanski, some individuals prefer avoiding uncertainty in a condition, closing mental uncertainty (cognitive closure) and having definite, stable and predictable circumstances. These choices increase the need for cognitive closure of an individual (Kruglanski and Webster, 1996). From this point of view, the need for cognitive closure is a structure that affect people's way of perceiving the social world. At the same time, the need for cognitive closure reflects an option for certainty and stability, openness and definite rules, definite answers to questions, uncertainty and lack of control. Individuals who need the closure dimension of personality tend to adopt stereotype judgments and are less inclined to accept variety. This structure is also related to accept rules, to reduce former beliefs and to accept routine (Todor, 2014). Individuals who have high need for cognitive closure want to reach fast decision making as soon as possible which also reflect needs for stability. In addition, they find conditions lacking closure to be repulsive and they become disturbed by the uncertainty. Finally, they are conservative since they are unwilling for their knowledge to be affected by alternative ideas or inconsistent evidences (Roets and Hiel, 2011).

In a study conducted on the samples of Europe, USA and Eastern Asia in order to test the intercultural invariance of the need for cognitive closure, it was determined that the concept of need for cognitive closure contains the same basic meaning and structure in different cultures and that the Need for Cognitive Closure Scale can be used for comparison between countries. The same study also observed that the need for cognitive closure is significantly higher in the samples of USA and Korea compared to the samples in Netherlands and Poland in particular (Kossowska et al., 2002).

150 million people with a common history live in a geography extending from Anatolia to China. A very intensive relation and cooperation started between Turkey and the societies on this geography in every fields particularly after 1991. This cooperation and solidarity are not at a desired level today. The most important reason behind that is the fact that the societies of Turkey and Central Asia do not sufficiently know each other. Several social psychology studies are needed in this matter. These studies will contribute greatly to the knowing of the people in these societies who lack sufficient relation and cooperation for centuries and thus to the development of public diplomacy. It is hoped that this study will draw attention to this need and requirement. On the other hand, it is believed that this study will meet this need even slightly.

This study intends to determine the differences among the university students of 3 countries with regards to the thinking styles, decision making styles and need for cognitive closure. It has been attempted to find questions to the following questions in line with this general objective.

The university students from Turkey, Uzbekistan and Kyrgyzstan;

i. In Which Thinking Styles do they have Different Characteristics?

ii. In Which Decision Making styles do they have Different Characteristics?

iii. Do they have Any Difference with Regards to the Need for Cognitive Closure?

\section{Method}

The study uses descriptive and relational screening method. The thinking styles, decision making styles and cognitive closure characteristics of the university students from Kyrgyzstan, Uzbekistan and Turkey were determined and compared.

\subsection{Population and Sample}

The general population of the study consists of the university students from Azerbaijan, Afghanistan, Kazakhstan, Kyrgyzstan, Mongolia, Uzbekistan, Tajikistan, Turkmenistan and Turkey. The study population consists of the students of the Kyrgyz-Turkish Manas University in the academic year of 2017 to 2018. Table 1 includes the information regarding the sample selected from the study population. 


\begin{tabular}{l|l|l|l|l|l|l}
\multicolumn{7}{c}{ Table-1. Sample of the Study } \\
\hline \multirow{2}{*}{ Country } & \multicolumn{2}{|l|}{ Female } & \multicolumn{2}{l|}{ Male } & \multicolumn{2}{c}{ Total } \\
\cline { 2 - 7 } & $\mathbf{N}$ & $\mathbf{\%}$ & $\mathbf{N}$ & $\mathbf{\%}$ & $\mathbf{N}$ & $\mathbf{\%}$ \\
\hline Kyrgyzstan & 38 & 31.4 & 51 & 28.7 & 89 & 29.8 \\
\hline Uzbekistan & 26 & 21.5 & 43 & 24.1 & 69 & 23.1 \\
\hline Turkey & 57 & 47.1 & 84 & 47.2 & 141 & 47.1 \\
\hline TOTAL & 121 & 40.5 & 178 & 59.5 & 299 & 100 \\
\hline
\end{tabular}

\subsection{Data Collection Tools}

Three scales were used in the research. First one is the thinking style inventory developed by Sternberg and Wagner (Sternberg and Wagner, 1992) on the basis of Mental Self-Government Theory. This tool consists of 13 sub scales called as legislative, executive, judicial, hierarchic, oligarchic, monarchic, anarchic, global, local, internal, external, liberal and conservative. Each subscale shows the dominant thinking style of an individual and is independent from the other dimensions (Fer, 2005). Various researchers adapted this scale in Turkey. The present study uses the 65-item form adapted by Buluş (2006). The alpha values for the 13 subscales of this form were calculated to be .81 while the average values varied between .66 (anarchic) and .93 (monarchic). The alpha values calculated for this research are .76 for legislative, .78 for executive, .76 for judicial, .80 for hierarchic, .83 for oligarchic, .90 for monarchic, .71 for anarchic, .77 for global, .76 for local, .79 for internal, .79 for external, .83 for liberal and .90 for conservative.

The second tool used in the study is the decision making styles developed by Scott and Bruce. The scale measures the individual differences in decision making styles used in approaching the problems in the decision making process. The 25 -item original form of the decision making style scale has a structure consisting of five sub dimensions including rational, intuitive, dependant, avoidant and spontaneous decision making styles. The internal consistency coefficients were found to be between .79 and .94 for each sub scale (Scott and Bruce, 1995). The scale was adapted to Turkish by Taşdelen (2002). In this adaptation work, the Cronbach alpha values of the five sub dimensions of KVSÖ were found to be .76 for rational decision making, .78 for intuitive decision making, .76 for dependant decision making, .79 for avoidant decision making and .79 for spontaneous decision making. This value was .74 for the all scale with 24 items (Taşdelen, 2002). The values calculated for the present study were $.78, .80$, $.75, .82, .82$ respectively and .78 for the whole scale. The results show that both scales can provide data with high consistency.

The last tool used in the study is the scale for the need for cognitive closure. The scale was developed by Kruglanski and Webster (1996) and revised by Roets and Hiel (2011). Roets and Hiel (2011) proved that the 15item version of the need for cognitive closure scale is identical with the 42-item form. The Turkish adaptation of this scale was used in the present study. The goodness of fit values indicate that the five-factor structure of the scale was confirmed for the sample of Turkey. In addition, it was observed that the standardized factor load values varied between 0,49 and 0,83. The factor load values of the need for cognitive closure scale are at a desired level. The internal consistency reliability of the scale was calculated to be .85 .

\subsection{Data Analysis}

The data were examined with the one-way variance analysis and the T2 test of Scheffe and Tamhane was applied to find the source of the difference. The significance level was accepted to be .05.

\section{Findings}

\subsection{Findings on the Thinking Styles}

Table 2 includes the results on the scores of the students of three countries with respect to the legislative, executive and judicial thinking styles under the functions dimension.

Table-2. Comparison of the Students of Three Countries with Respect to the Legislative, Executive and Judicial Thinking Styles under the Functions Dimension

\begin{tabular}{|c|c|c|c|c|c|c|}
\hline Variable & Country & $N$ & $M$ & SS & $F$ & Scheffe Test Result (Source of Difference) \\
\hline Legislative & $\begin{array}{l}\text { Turkey } \\
\text { Uzbekistan } \\
\text { Kyrgyzstan }\end{array}$ & $\begin{array}{l}141 \\
69 \\
89\end{array}$ & $\begin{array}{l}21.07 \\
17.35 \\
20.04\end{array}$ & $\begin{array}{l}2.84 \\
3.88 \\
3.45\end{array}$ & $29.73^{* *}$ & $\begin{array}{l}\text { Turkey-Uzbekistan } \\
\text { Kyrgyzstan-Uzbekistan }\end{array}$ \\
\hline Executive & $\begin{array}{l}\text { Turkey } \\
\text { Uzbekistan } \\
\text { Kyrgyzstan } \\
\end{array}$ & $\begin{array}{l}141 \\
69 \\
89 \\
\end{array}$ & $\begin{array}{l}19.77 \\
17.16 \\
18.55 \\
\end{array}$ & $\begin{array}{l}3.53 \\
3.45 \\
3.22 \\
\end{array}$ & $13.86^{* * *}$ & $\begin{array}{l}\text { Turkey -Uzbekistan } \\
\text { Turkey-Kyrgyzstan } \\
\text { Kyrgyzstan-Uzbekistan }\end{array}$ \\
\hline Judicial & $\begin{array}{l}\text { Turkey } \\
\text { Uzbekistan } \\
\text { Kyrgyzstan }\end{array}$ & $\begin{array}{l}141 \\
69 \\
89\end{array}$ & $\begin{array}{l}19.04 \\
16.22 \\
17.84\end{array}$ & $\begin{array}{l}3.71 \\
3.30 \\
3.51\end{array}$ & $14.76^{* * *}$ & $\begin{array}{l}\text { Turkey-Uzbekistan } \\
\text { Turkey-Kyrgyzstan } \\
\text { Kyrgyzstan-Uzbekistan }\end{array}$ \\
\hline
\end{tabular}

Note: ${ }^{* *} p<.001$

In the legislative thinking style, the average of the sample of Turkey is $(M=21.07, s s=2.84)$, Uzbekistan $(M$ $=17.35$, ss $=3.88)$ and Kyrgyzstan $(M=20.04, s s=3.45)$. According to the result of the variance analysis, significant difference was found between the three sample groups in the legislative style $(F=29.73 ; p<.001)$. According to the Scheffe Test, it was found that this difference was caused by the sample of "Turkey-Uzbekistan" and "Kyrgyzstan-Uzbekistan" $\left(M_{t}-M_{2}=3.72\right)$. These findings show that the university students of Turkey and Kyrgyzstan have more legislative thinking style than the Uzbek students.

Turkey has the highest average in the executive dimension $(M=19.77$, ss $=2.84)$ while Uzbekistan sample has the lowest average $(M=17.16, s s=3.45)$. There is a significant difference between the three groups with respect to the executive thinking style $(F=13.86 ; p<.000)$. When we look at the source of the difference, the followings were found: "Turkey-Uzbekistan $\left(M_{l}-M_{2}=2.61\right)$ ", "Turkey-Kyrgyzstan $\left(M_{l}-M_{s}=1.22\right)$ " and 
"Kyrgyzstan-Uzbekistan $\left(M_{2}-M_{3}=1.39\right)$ ". The university students of Turkey have a significant executive thinking style compared to the other two groups. Similar results were found in the judicial thinking style $\left(M_{l}=19.04 ; \mathrm{M}_{2}=\right.$ 16.22 and $\left.M_{s}=18.03\right)$. This scores obtained with regards to this style are significantly different $(F=14.76$; $p<.000)$. This difference was based on: Turkey-Uzbekistan $\left(M_{l}-M_{2}=2.83\right)$ ", "Turkey-Kyrgyzstan $\left(M_{l}-M_{s}=1.20\right)$ " and "Kyrgyzstan-Uzbekistan $\left(M_{l}-M_{s}=1.62\right)$ ". As a result, the sample of Turkey is more dominant than the other two groups in the legislative, executive and judicial thinking styles under the functions dimension.

Table 3 includes the results on the scores of the students from three countries with respect to the hierarchic, oligarchic, monarchic and anarchic thinking styles under the forms dimension.

Table-3. Comparison of the Students from Three Countries with respect to the Hierarchic, Oligarchic, Monarchic and Anarchic Thinking Styles under the Forms Dimension

\begin{tabular}{|c|c|c|c|c|c|c|}
\hline Variable & Country & $\boldsymbol{N}$ & $M$ & ss & $\boldsymbol{F}$ & Scheffe Test Result (Source of Difference) \\
\hline Monarchic & $\begin{array}{l}\text { Turkey } \\
\text { Uzbekistan } \\
\text { Kyrgyzstan }\end{array}$ & $\begin{array}{l}141 \\
69 \\
89\end{array}$ & $\begin{array}{l}16.84 \\
16.89 \\
18.85\end{array}$ & $\begin{array}{l}3.16 \\
2.77 \\
3.42 \\
\end{array}$ & $3.083^{*}$ & Turkey-Kyrgyzstan \\
\hline Hierarchic & $\begin{array}{l}\text { Turkey } \\
\text { Uzbekistan } \\
\text { Kyrgyzstan }\end{array}$ & $\begin{array}{l}141 \\
69 \\
89\end{array}$ & $\begin{array}{l}19.49 \\
16.14 \\
18.80\end{array}$ & $\begin{array}{l}3.88 \\
3.47 \\
3.45\end{array}$ & $19.722^{*} *$ & $\begin{array}{l}\text { Turkey-Uzbekistan } \\
\text { Kyrgyzstan-Uzbekistan }\end{array}$ \\
\hline Oligarchic & $\begin{array}{l}\text { Turkey } \\
\text { Uzbekistan } \\
\text { Kyrgyzstan }\end{array}$ & $\begin{array}{l}141 \\
69 \\
89\end{array}$ & $\begin{array}{l}15.83 \\
17.00 \\
17.24\end{array}$ & $\begin{array}{l}3.65 \\
3.28 \\
3.71\end{array}$ & $4.989 *$ & Turkey-Kyrgyzstan \\
\hline Anarchic & $\begin{array}{l}\text { Turkey } \\
\text { Uzbekistan } \\
\text { Kyrgyzstan }\end{array}$ & $\begin{array}{l}141 \\
69 \\
89\end{array}$ & $\begin{array}{l}17.39 \\
16.46 \\
17.08\end{array}$ & $\begin{array}{l}3.51 \\
3.11 \\
3.73\end{array}$ & 1.650 & \\
\hline
\end{tabular}

Table 3 includes the results of the scores of the students of the three countries with respect to the with respect to the hierarchic, oligarchic, monarchic and anarchic thinking styles under the forms dimension. The averages of the samples of the countries in the monarchic thinking style are as follows: Turkey $\left(M_{i}=16.84, s s=3.10\right)$, Uzbekistan $\left(M_{2}=17.35, s s=2.77\right)$ and Kyrgyzstan $\left(M_{s}=18.85\right.$, ss $\left.=3.42\right)$. According to the result of the variance analysis, significant difference was found between the three sample group $(F=3.083 ; p<.047)$. According to the result of the Scheffe test, this difference was caused by the samples of "Turkey-Kyrgyzstan $\left(M_{l}-M_{s}=-2.01\right)$ ". These findings show that the university students of Kyrgyzstan have more monarchic thinking style than the sample of Turkey. In the hierarchic thinking style dimension, the highest average was found in the sample of Turkey $\left(M_{l}=\right.$ 19.49 , ss $=3.88)$ and the lowest average was found in the sample of Uzbekistan $\left(M_{s}=16.14\right.$, ss $\left.=3.47\right)$. The difference between the three groups with respect to the hierarchic thinking style is significant $(F=19.722 ; p$ $<.000)$. When we look at the source of the difference, the followings are found: "Turkey-Uzbekistan" $\left(M_{1}-M_{2}=\right.$ $3.35)$ and "Kyrgyzstan-Uzbekistan" $\left(M_{2}-M_{s}=2.66\right)$. The university students of Turkey and Kyrgyzstan have more hierarchic thinking style than the students from Uzbekistan.

In the oligarchic thinking style, the averages are as follows: Turkey $\left(M_{l}=15.83\right.$, ss $\left.=3.65\right)$, Uzbekistan $\left(M_{2}=\right.$ $17.00, s s=3.28)$ and Kyrgyzstan $\left(M_{s}=17.24, s s=3.71\right)$. The scores obtained in this style significantly different $(F$ $=4.989 ; p<.007)$. This difference was found to be based on the result that "Turkey-Kyrgyzstan $\left(M_{i}-M_{s}=-1.41\right)$ ". In the anarchic thinking style, the averages of the students of the three countries were close to each other $\left(M_{i}=\right.$ $17.39, s s=3.51 ; M_{2}=16.46, s s=3.11$; and $\left.M_{s}=17.08 ; s s=3.73\right)$. No significant difference was found in the analysis made in this dimension $(F=1.650, p>.05)$. As a result, it was found that the students from Kyrgyzstan had higher average than the other groups in the monarchic thinking style, Turkey in the hierarchic thinking style, Kyrgyzstan in the oligarchic thinking style and Turkey in the anarchic thinking style. The differences were found to be significant in the first three of these dimensions while there was no significant difference among the students of both countries in the anarchic thinking style.

Table 4 includes results on the scores of the students of the three countries with respect to the global and local thinking styles under the dimensions of levels.

Table-4. Comparison of the Students of the Three Countries with respect to the Global and Local Thinking Styles under the Dimensions of Levels

\begin{tabular}{l|l|l|l|l|l|l}
\hline Variable & Country & $\boldsymbol{N}$ & $\boldsymbol{M}$ & $\boldsymbol{s}$ & $\boldsymbol{F}$ & Scheffe Test Result (Source of Difference) \\
\hline \multirow{3}{*}{ Global } & Turkey & 141 & 14.66 & 4.64 & & \\
& Uzbekistan & 69 & 15.84 & 2.87 & $6.05^{*}$ & Turkey-Kyrgyzstan \\
& Kyrgyzstan & 89 & 16.51 & 3.79 & & \\
\hline \multirow{3}{*}{ Local } & Turkey & 141 & 16.38 & 4.11 & & \\
& Uzbekistan & 69 & 16.59 & 3.11 & $3.52^{*}$ & Turkey-Kyrgyzstan \\
& Kyrgyzstan & 89 & 17.69 & 3.57 & & \\
\hline
\end{tabular}

"p<.005; ${ }^{* *} p<.001$

In the global thinking style under the levels dimension, the averages are as follows: Turkey $\left(M_{i}=14.66, s s=\right.$ 4.64), Uzbekistan $\left.M_{2}=15.84, s s=2.87\right)$ and Kyrgyzstan $\left(M_{s}=16.51, s s=3.79\right)$. The scores obtained with respect to this style have significant differences $(F=6.05 ; p<.003)$. This difference was found to be caused by "TurkeyKyrgyzstan (M1-M3=-1.85)". Among the countries of three countries, the Kyrgyz students have the highest average in the local thinking style $\left(M_{t}=16.38\right.$, ss $=4.11 ; M_{2}=16.59$, ss $=3.11$ and $M_{s}=17.69$, ss $\left.=3.57\right)$. The analysis in this dimension showed that the difference was significant 
$(F=3.52, p<.05)$. The Tamhane test that was applied indicated that the cause of this difference was based on the sample of Turkey - Kyrgyzstan $\left(M_{l}-M_{s}=1.31\right)$. As a result, Kyrgyzstan had significantly higher scores than Turkey in the global and local thinking styles.

Table 5 includes the results of the students of the three countries with respect to the internal and external thinking styles under the scopes dimension.

Table-5. Comparison of the Students of the Three Countries with respect to the Internal and External Thinking Styles under the Scopes Dimension

\begin{tabular}{|c|c|c|c|c|c|c|}
\hline Variable & Country & $N$ & $M$ & SS & $F$ & Scheffe Test Result (Source of Difference) \\
\hline Internal & $\begin{array}{l}\text { Turkey } \\
\text { Uzbekistan } \\
\text { Kyrgyzstan }\end{array}$ & $\begin{array}{l}141 \\
69 \\
89\end{array}$ & $\begin{array}{l}17.80 \\
16.64 \\
18.35\end{array}$ & $\begin{array}{l}4.00 \\
3.22 \\
3.53 \\
\end{array}$ & $4.27 *$ & $\begin{array}{l}\text { Turkey-Uzbekistan } \\
\text { Uzbekistan-Kyrgyzstan }\end{array}$ \\
\hline External & $\begin{array}{l}\text { Turkey } \\
\text { Uzbekistan } \\
\text { Kyrgyzstan }\end{array}$ & $\begin{array}{l}141 \\
69 \\
89\end{array}$ & $\begin{array}{l}17.03 \\
17.26 \\
18.11\end{array}$ & $\begin{array}{l}4.08 \\
3.64 \\
3.44\end{array}$ & 2.30 & \\
\hline
\end{tabular}

In the internal thinking styles in the dimension of scopes, the averages are as follows: Turkey $\left(M_{1}=17.80, s s=\right.$ 4.00), Uzbekistan $\left(M_{2}=16.64, s s=3.22\right)$ and Kyrgyzstan $\left(M_{s}=18.35\right.$, ss $\left.=3.53\right)$. The scores obtained with regards to this style have significant difference $(F=4.27 ; p<.015)$. This difference was found to be caused by "TurkeyUzbekistan" $\left(M_{1}-M_{2}=1.16\right)$ and "Uzbekistan-Kyrgyzstan $\left(M_{2}-M_{3}=-1.71\right)$ ". In the external thinking style, the averages of the students of the three countries were as follows: $\left(M_{1}=17.03 ; M_{2}=17.26\right.$ and $\left.M_{3}=18.11\right)$. The analysis in this dimension showed the difference was not significant $(F=2.30, p>.05)$. As a result, Turkish and Kyrgyz students had significantly higher scores in the internal thinking style under the scopes dimension. In the external thinking style, there is no significant difference among the three groups of university students.

Table-6. Comparison of the Students of Three Countries with regards to the Liberal and Conservative Thinking Styles under the Leanings Dimension

\begin{tabular}{l|l|l|l|l|l|l}
\hline Variable & Country & $\boldsymbol{N}$ & $\boldsymbol{M}$ & $\boldsymbol{s S}$ & $\boldsymbol{F}$ & Scheffe Test Result (Source of Difference) \\
\hline \multirow{3}{*}{ Liberal } & Turkey & 141 & 18.82 & 4.29 & & \\
& Uzbekistan & 69 & 17.49 & 3.23 & $2.98^{*}$ & Turkey-Uzbekistan \\
& Kyrgyzstan & 89 & 18.30 & 3.19 & & \\
\hline \multirow{3}{*}{ Conservative } & Turkey & 141 & 13.70 & 4.64 & & Turkey-Uzbekistan \\
& Uzbekistan & 69 & 16.13 & 3.45 & $17.41^{*} *$ & Turkey-Kyrgyzstan \\
\hline
\end{tabular}

${ }^{*} p<.005 ; \quad{ }^{* * *} p<.001$

Table 6 includes the results on the scores of the students of three countries with regards to the liberal and conservative thinking styles under the leanings dimension.

In the liberal thinking style, the averages of the samples are as follows: Turkey $\left(M_{l}=18.82\right.$, ss $\left.=4.29\right)$, Uzbekistan $\left(M_{2}=17.49\right.$, ss $\left.=3.23\right)$ and Kyrgyzstan $\left(M_{s}=18.30\right.$, ss = 3.19). According to the result of the variance analysis, a significant difference was found among the three sample groups in the liberal thinking style $(F=2.98 ; p$ $<.048)$. According to the result of the Scheffe test, this difference was caused by the sample of Turkey-Uzbekistan $\left(M_{l}-M_{2}=1.32\right)$. These findings show that the university students of Turkey have more liberal thinking style than the students from Uzbekistan.

In the conservative thinking style, the highest averages were found in the students from Kyrgyzstan $(M 3=$ $16.91, s s=4.20)$ and Uzbekistan $\left(M_{2}=16.13, s s=3.45\right)$. Turkish university students have the lowest average in the conservative thinking style $\left(M_{l}=13.70\right.$, ss $\left.=4.64\right)$. There is a significant difference among the three groups with respect to the conservative thinking style $(F=17.40 ; p<.000)$. The source of the difference was found to be caused by "Turkey-Uzbekistan" $\left(M_{l}-M_{2}=-2.42\right)$ and "Turkey-Kyrgyzstan $\left(M_{l}-M_{s}=-3.20\right)$. The Kyrgyz and Uzbek university students have a significantly conservative thinking style. As a result, the sample of Turkey has the least conservative thinking style among the three groups of students in the liberal and conservative thinking styles under the dimension of leanings.

\subsection{Findings on the Decision Making Styles}

Table 7 includes the findings on the comparison of the Turkish, Uzbek and Kyrgyz university students with respect to their decision making styles. In reviewing Table 7, there are significant differences among the Turkish, Uzbek and Kyrgyz students in the rational, avoidant and spontaneous decision making styles among the 5 decision making styles. In the intuitive and dependant decision making styles, no significant difference was found between the three sample groups. In the rational decision making style, Turkish students have the highest average $\left(M_{l}=\right.$ 20.82, ss $=3.06)$ followed by the Kyrgyz students $\left(M_{s}=19.80\right.$, ss $\left.=3.54\right)$. It was found that the Uzbek students have the lowest average among the three groups $\left(M_{2}=17.64, s s=4.16\right)$. A significant difference was found among the three groups with respect to the rational decision making style $(F=19.229, p<.000)$. It is understood that this difference arises from the sample of Turkey and Uzbekistan $\left(M_{1}-M_{2}=3.18\right)$ and the sample of Uzbekistan and Kyrgyzstan $\left(M_{2}-M_{s}=-2.16\right)$. In the avoidant decision making style, the Kyrgyz students have the highest average $(M 3=16.29$, ss $=4.11)$.

In this style, the averages of the Kyrgyz students and the Uzbek students are very close to each other $\left(M_{2}=\right.$ $15.97, s s=4.20)$. Turkish students have the lowest average $\left(M_{l}=12.47, s s=5.24\right)$. There is a significant difference among the three groups $(F=22.907, p<.000)$. This significance is caused by the sample of Turkey - Uzbekistan $\left(M_{1}-M_{2}=-3.49\right)$ and the sample of Turkey-Kyrgyzstan $\left(M_{1}-M_{s}=-3.82\right)$. 
Table-7. Comparison of the Turkish, Uzbek and Kyrgyz University Students with respect to their Decision Making Styles

\begin{tabular}{|c|c|c|c|c|c|c|}
\hline Variable & Country & $\boldsymbol{N}$ & $M$ & Ss & $\boldsymbol{F}$ & Scheffe Test Result (Source of Difference) \\
\hline $\begin{array}{l}\text { Rational } \\
\text { decision making }\end{array}$ & $\begin{array}{l}\text { Turkey } \\
\text { Uzbekistan } \\
\text { Kyrgyzstan }\end{array}$ & $\begin{array}{l}141 \\
69 \\
89\end{array}$ & $\begin{array}{l}20.82 \\
17.64 \\
19.80\end{array}$ & $\begin{array}{l}3.06 \\
4.16 \\
3.54\end{array}$ & $19.229 * *$ & Turkey-Uzbekistan Uzbekistan-Kyrgyzstan \\
\hline $\begin{array}{l}\text { Intuitive } \\
\text { decision making }\end{array}$ & $\begin{array}{l}\text { Turkey } \\
\text { Uzbekistan } \\
\text { Kyrgyzstan }\end{array}$ & $\begin{array}{l}141 \\
69 \\
89\end{array}$ & $\begin{array}{l}18.95 \\
17.84 \\
18.34\end{array}$ & \begin{tabular}{|l|}
4.38 \\
3.63 \\
3.64
\end{tabular} & 1.928 & \\
\hline $\begin{array}{l}\text { Dependant } \\
\text { decision making }\end{array}$ & $\begin{array}{l}\text { Turkey } \\
\text { Uzbekistan } \\
\text { Kyrgyzstan }\end{array}$ & $\begin{array}{l}141 \\
69 \\
89\end{array}$ & $\begin{array}{l}13.81 \\
13.71 \\
14.12\end{array}$ & $\begin{array}{l}3.32 \\
3.43 \\
3.35\end{array}$ & .416 & \\
\hline $\begin{array}{l}\text { Avoidant } \\
\text { decision making }\end{array}$ & $\begin{array}{l}\text { Turkey } \\
\text { Uzbekistan } \\
\text { Kyrgyzstan }\end{array}$ & $\begin{array}{l}141 \\
69 \\
89\end{array}$ & $\begin{array}{l}12.47 \\
15.97 \\
16.29\end{array}$ & $\begin{array}{l}5.24 \\
4.20 \\
4.11\end{array}$ & $22.907 * *$ & Turkey-Uzbekistan Turkey-Kyrgyzstan \\
\hline $\begin{array}{l}\text { Spontaneous } \\
\text { decision making }\end{array}$ & $\begin{array}{l}\text { Turkey } \\
\text { Uzbekistan } \\
\text { Kyrgyzstan }\end{array}$ & $\begin{array}{l}141 \\
69 \\
89\end{array}$ & $\begin{array}{l}13.71 \\
15.64 \\
15.46\end{array}$ & $\begin{array}{l}4.49 \\
4.53 \\
4.06\end{array}$ & $5.114^{*}$ & Turkey-Uzbekistan Turkey-Kyrgyzstan \\
\hline
\end{tabular}

Totally similar case was found in the spontaneous decision making style. The Turkish sample has the lowest score in this style $(M 1=13.71, s s=4.49)$. Kyrgyz students $\left(M_{s}=15.46, s s=4.06\right)$ and Uzbek students $\left(M_{2}=15.64\right.$, $s s=4.53)$ have very close averages. Significant differences were found among the three groups with respect to spontaneous decision making $(F=5.114, p<.000)$. This difference is caused by the by the sample of Turkey Uzbekistan $\left(M_{1}-M_{2}=-1.93\right)$ and the sample of Turkey-Kyrgyzstan $\left(M_{t}-M_{s}=-1.74\right)$.

As a result, it was observed that the rational, avoidant and spontaneous decision making styles of the Turkish, Uzbek and Kyrgyz students were different. The Turkish university students have more rational decision making style and less spontaneous decision making style than the other two groups. It was observed that the students from Kyrgyzstan and Uzbekistan have similar qualities with respect to the avoidant and spontaneous decision making styles.

\subsection{Findings on the Need for Cognitive Closure}

Table 8 includes the findings on the comparison of the Turkish, Uzbek and Kyrgyz university students with respect to cognitive closure.

In the simplest explanation, cognitive closure is defined to be the need to reach a definitive information instead of chaos and uncertainty in a certain subject, and the motive to simplify knowledge and to avoid uncertainty in a decision making condition. Cognitive closure is the variable with the most difference among the three groups in the study. The sample of Turkey has the lowest average in the sub dimension of preference for order and structure $\left(M_{l}\right.$ $=11.93, s s=3.05)$ while Kyrgyzstan has the highest average $(M 3=13.12$, ss $=3.16)$. In this dimension, it was found that the scores of the Turkish, Kyrgyz and Uzbek students are significantly different $(F=5.76, p<.05)$. This difference is caused by the samples of Turkey-Kyrgyzstan $\left(M_{l}-M_{s},=-1.19\right)$ and the sample of Turkey-Uzbekistan $\left(M_{1}-M_{2}=-1.16\right)$. The university students from Kyrgyzstan and Uzbekistan didn't have any difference in the preference for order and structure dimension of cognitive closure.

Table-8. Comparison of the Turkish, Uzbek and Kyrgyz University Students with respect to Cognitive closure

\begin{tabular}{|c|c|c|c|c|c|c|}
\hline Variable & Country & $\boldsymbol{N}$ & $M$ & sS & $\boldsymbol{F}$ & Scheffe Test Result (Source of Difference) \\
\hline $\begin{array}{lr}\begin{array}{l}\text { Preference } \\
\text { order }\end{array} & \text { for } \\
\text { structure } & \text { and }\end{array}$ & $\begin{array}{l}\text { Turkey } \\
\text { Uzbekistan } \\
\text { Kyrgyzstan }\end{array}$ & $\begin{array}{l}141 \\
69 \\
89\end{array}$ & $\begin{array}{l}11.93 \\
13.09 \\
13.12\end{array}$ & $\begin{array}{l}3.05 \\
2.65 \\
3.16\end{array}$ & $5.760 *$ & $\begin{array}{l}\text { Turkey - Uzbekistan } \\
\text { Turkey - Kyrgyzstan }\end{array}$ \\
\hline $\begin{array}{ll}\text { Desire } & \text { for } \\
\text { predictability } & \end{array}$ & $\begin{array}{l}\text { Turkey } \\
\text { Uzbekistan } \\
\text { Kyrgyzstan }\end{array}$ & $\begin{array}{l}141 \\
69 \\
89\end{array}$ & $\begin{array}{l}9.77 \\
11.97 \\
12.64\end{array}$ & $\begin{array}{l}2.40 \\
3.04 \\
2.86\end{array}$ & $35.302 * *$ & $\begin{array}{l}\text { Turkey - Uzbekistan } \\
\text { Turkey - Kyrgyzstan }\end{array}$ \\
\hline Decisiveness & $\begin{array}{l}\text { Turkey } \\
\text { Uzbekistan } \\
\text { Kyrgyzstan }\end{array}$ & $\begin{array}{l}141 \\
69 \\
89\end{array}$ & $\begin{array}{l}11.95 \\
13.30 \\
14.08\end{array}$ & $\begin{array}{l}2.41 \\
2.77 \\
2.45\end{array}$ & $20.745 * *$ & $\begin{array}{l}\text { Turkey - Uzbekistan } \\
\text { Turkey - Kyrgyzstan }\end{array}$ \\
\hline $\begin{array}{l}\text { Discomfort with } \\
\text { ambiguity }\end{array}$ & $\begin{array}{l}\text { Turkey } \\
\text { Uzbekistan } \\
\text { Kyrgyzstan }\end{array}$ & $\begin{array}{l}141 \\
69 \\
89\end{array}$ & $\begin{array}{l}12.18 \\
10.72 \\
14.06\end{array}$ & $\begin{array}{l}2.63 \\
1.77 \\
3.15\end{array}$ & $32.215^{* *}$ & $\begin{array}{l}\text { Turkey - Uzbekistan } \\
\text { Turkey - Kyrgyzstan } \\
\text { Kyrgyzstan-Uzbekistan }\end{array}$ \\
\hline Close-mindedness & $\begin{array}{l}\text { Turkey } \\
\text { Uzbekistan } \\
\text { Kyrgyzstan }\end{array}$ & $\begin{array}{l}141 \\
69 \\
89\end{array}$ & $\begin{array}{l}9.05 \\
13.04 \\
12.04\end{array}$ & $\begin{array}{l}2.95 \\
2.92 \\
3.49\end{array}$ & $46.787 * *$ & $\begin{array}{l}\text { Turkey - Uzbekistan } \\
\text { Turkey - Kyrgyzstan }\end{array}$ \\
\hline $\begin{array}{l}\text { Cognitive closure } \\
\text { TOTAL }\end{array}$ & $\begin{array}{l}\text { Turkey } \\
\text { Uzbekistan } \\
\text { Kyrgyzstan }\end{array}$ & $\begin{array}{l}141 \\
69 \\
89\end{array}$ & $\begin{array}{l}54.89 \\
62.13 \\
65.98\end{array}$ & $\begin{array}{l}10.54 \\
10.52 \\
12.20\end{array}$ & $29.247 * *$ & $\begin{array}{l}\text { Turkey - Uzbekistan } \\
\text { Turkey - Kyrgyzstan }\end{array}$ \\
\hline
\end{tabular}

Similar results were obtained in the dimension of the desire for predictability. In this dimension, Turkish students have the lowest average $\left(M_{i}=9.77, s s=2.40\right)$ and the Kyrgyz students have the highest average $\left(M_{s}=\right.$ $12.64, s s=2.86)$. In the dimension for the desire for predictability, the average of the Uzbek students is $\left(M_{2}=\right.$ $11.97, s s=3.04)$. The scores in this dimension varied significantly $(F=35.301, p<.05)$. The source of the difference is the sample of Turkey-Uzbekistan $\left(M_{1}-M_{2}=-2.20\right)$ and the sample of Turkey-Kyrgyzstan $\left(\mathrm{M}_{1}-\mathrm{M}_{3}=-2.88\right)$. 
In the dimension of decisiveness, Kyrgyz students have the highest average $\left(\mathrm{M}_{3}=14.08, s s=2.45\right)$ and the Turkish students have the lowest average $\left(M_{l}=11.95\right.$, ss $\left.=2.41\right)$. The average of the Uzbek students is between the two other groups $\left(M_{2}=13.30, s s=2.77\right)$. The difference was found to be significant $(F=20.745, p<.05)$ and caused by the samples of Turkey-Uzbekistan $\left(M_{i}-M_{2}=1.35\right)$ and Turkey-Kyrgyzstan $\left(M_{i}-M_{s}=2.13\right)$. No significant difference was found between the dimension of decisiveness among the students of Kyrgyzstan and Uzbekistan. **

In the dimension of discomfort with ambiguity, the Kyrgyz students have the highest average $\left(M_{s}=14.06, s s=\right.$ 3.15). The average of the Turkish students in this dimension is $\left(M_{i}=12.18, s s=2.63\right)$. Uzbek students have the lowest average $\left(M_{2}=10.72\right.$, ss $\left.=1.77\right)$. There is a significant difference in the dimension of discomfort with ambiguity among the Turkish, Uzbek and Kyrgyz students $(F=32.215, p<.05)$. The cause of the difference is the sample of Turkey-Uzbekistan $\left(M_{l}-M_{2}=1.46\right)$, the sample of Turkey-Kyrgyzstan $\left(M_{l}-M_{s}=-1.88\right)$ and the sample of Kyrgyzstan-Uzbekistan $\left(M_{s}-M_{2}=3.35\right)$

In the dimension of close-mindedness, Uzbek students have the highest average $\left(M_{2}=13.04, s s=2.92\right)$ and the Turkish students have the lowest average $\left(M_{i}=9.05\right.$, ss $\left.=2.95\right)$. The average of the Kyrgyz students is $\left(M_{s}=\right.$ $12.04, s s=3.49)$. In the dimension of close-mindedness, there is a significant difference between the Turkish, Uzbek and Kyrgyz students $(F=46.787, p<.05)$. The cause of the difference is the sample Turkey and Uzbekistan $\left(M_{i}-M_{2}=-3.99\right)$ and the Turkey-Kyrgyzstan $\left(M_{l}-M_{s}=-2.99\right)$.

The evaluation on the total scores in the need for cognitive closure supports the explanations above. Kyrgyz students have the highest need for cognitive closure $\left(M_{s}=65.98, s s=12.20\right)$. Turkish students have the lowest need for cognitive closure $\left(M_{1}=54.89\right)$. The average of the Uzbek students from the total of the scale is $\left(M_{2}=\right.$ $62.13, s s=10.52)$. This difference was found statistically significant $(F=29.247, p<.000)$. The source of the difference was found the be the sample of Turkey-Uzbekistan $\left(M_{1}-M_{2}=-7.24\right)$ and the sample of TurkeyKyrgyzstan $\left(M_{l}-M_{s}=11.07\right)$. No significant difference was found in the sample of Kyrgyzstan-Uzbekistan.

As a result, Kyrgyz students have higher averages of cognitive closure in the dimensions of preference for order and structure, desire for predictability, decisiveness and discomfort with ambiguity. Uzbek students have higher averages in the dimension of close-mindedness. The university students from Turkey are observed to be the group with the lowest need for cognitive closure.

\section{Discussion}

Thinking, decision making and cognitive closure are the features that have a multidimensional effect on every aspects of our lives. These three concepts are effective for both problem solution and problem creating in individual and social lives. Knowing the characteristics of the individuals and social groups with respect to thinking, decision making and cognitive closure will support every kinds of communication and cooperation as well as leading to healthier evaluation of people and societies for each other resulting in less conflict and more cooperation. This study compares the thinking and decision making styles and cognitive closure qualities of the Turkish, Uzbek and Kyrgyz university students and found significant differences among the students of these three societies that are accepted to be geographically and culturally close to each other. In eleven of the thirteen thinking styles, there are difference between the Turkish, Uzbek and Kyrgyz students. No difference was found among them only in the anarchic and external thinking styles. Differences were found in three of the five decision making styles where there was no differences in the intuitive and dependent decision making styles. The biggest difference among the Turkish, Uzbek and Kyrgyz university students was observed in the field of cognitive closure. No difference was found between the Uzbek and Kyrgyz students in the all of the dimensions of cognitive closure i.e. preference for order and structure, desire for predictability, decisiveness and close mindedness as well as in the total score of the scale. The only difference between these two groups was in the dimension of discomfort with ambiguity. On the other hand, there are significant differences between the Turkish and Uzbek students and between the Turkish and Kyrgyz students. The need for cognitive closure is the highest among the Kyrgyz students and the lowest in the Turkish students. This study on the thinking styles was based on the Theory of Self-government. Based on the explanations of the thinking styles of the theory (Garcia and Hughes, 2000; Zhang and Huang, 2001; Bernardo et al., 2002; Balkis and Isiker, 2005; Fer, 2005). Turkish, Uzbek and Kyrgyz students were revealed to have the following characteristics.

Turkish university students have characteristics of creating, formulating, planning, respecting rules, following instructions, evaluating different views and opinions, analysing, dealing with multiple objectives, being systematic, trying new methods and being innovative.

It can be said that the Kyrgyz university students prefer to have their minds deal with one single matter and to focus on it. The basic thinking qualities of the Kyrgyz students are found to be dealing with general and abstract thoughts rather than details, doing the works alone, using the usual methods and disfavouring changes. Uzbek university students were not found to have a style where they have higher scores than the other two groups in any of the 13 thinking styles. When we compare the thinking styles among the Uzbek students, they have higher scores in liberal thinking and lowest scores in global thinking.

The section of the study for decision making styles was based on the approach of Scott and Bruce (1995). In reviewing within this theoretical framework, Turkish university students prefer choosing the optimum alternative after making searches and examination on the circumstance to be decided. Kyrgyz university students have the tendency to get away from the decision and to avoid the decision making responsibility. Uzbek students have the tendency to make spontaneous decisions based on the current conditions.

The dimension of cognitive closure is the section with most difference. The students from three cultures were found to be differenced in all sub dimensions of the need for cognitive closure. This difference was found to be the most between the Turkish university students and the other students, either from Kyrgyzstan or Uzbekistan. The need for cognitive closure determines whether the individual facing a choice has a quality based or alternative based information seeking style (Kruglanski and Webster, 1996). Individuals with need for cognitive closure of different levels use different strategies for information search. Some individuals choose searching for more options, while others choose to decide immediately even if they have less knowledge (Hiel and Mervielde, 2005). The need 
for cognitive closure is defined to be choice by a person facing a decision for any option instead of ongoing uncertainty. When we look at the results of the study based on this theoretical foundation, Turkish university students have the lowest need for cognitive closure. No difference was observed between the Kyrgyz and Uzbek students with respect to cognitive closure. Turkish university students have significantly lower scores from the Uzbek and Kyrgyz students in all sub dimensions of the need for cognitive closure. On the other hand, Uzbek and Kyrgyz students are different from each other only in the dimension of discomfort with ambiguity.

There are several studies on the need for cognitive closure including intercultural comparisons. These studies mainly cover the samples of Korea, China, Japan and America where researchers argue that cognitive closure cannot be associated with Eastern culture or Western culture (Yeonyeob, 2011); (Mannetti et al., 2002) while some researchers argue that the difference in cognitive closure is based on the impact of the eastern and western cultures on the individual (Guess, 2004); (Zhang, 2002).

Several researchers in the literature argued that the cultural expectations and values are represented in the mind of an individual and guiding in thinking and selecting the decision making strategies (Emamipour and Esfandabad, 2013; Oliveira and Nisbett, 2017). Many previous studies attempted to reveal the differences between cultures. Most studies were on the samples of America, Japan and China. Majority of these studies found that the thinking and decisions processes of individuals were affected by the individual and collectivist values. Again, in many of these studies, it was reported that the Asian thinking styles are not realistic but superficial and dependant while the Western societies have deep, critical and independent thinking styles (Zhang, 2002; Emamipour and Esfandabad, 2013).

There have been criticisms recent years on the studies that look for a difference between cultures on thinking and decision making. While the reliability of the studies conducted by the measurement tools drafted in the Western culture is questioned (Tipandjan, 2010) it was emphasized that the analytical thinking style observed in the Western cultures cannot be referred to be a superiority and that the dialectical or holistic thinking styles which are more common in the Asian societies have also many superior sides (Oliveira and Nisbett, 2017). It was argued that analytical thinking may be useful for science and daily life but dialectical thinking may also lead to more correct results or more useful decisions than analytical thinking (Oliveira and Nisbett, 2017). Our study also adopts the view that each thinking style may have strong sides and useful functions for problem solving. What matters is that the individuals have knowledge about the thinking and decision making styles of each other during an intercultural contact. This will support communication and cooperation while reducing conflicts. Therefore, it is believed that the thinking and decision making styles of different cultures should be taught to students in schools.

On the other hand, there are studies in increasing numbers that emphasize that the thinking and decision making styles and the cultural effects on these styles are dynamic, not static and change in time (Emamipour and Esfandabad, 2013). It was found that the legislative, judicial, monarchic, hierarchic, external and liberal thinking styles were significantly reduced among the students between 2000 and 2011.

\section{Limitations and Recommendations}

The study has three important limitations. First, the study is limited with 3 countries. The Asian countries other than these three countries are out of the scope of the study. Secondly, the age group where the thinking styles, decision making styles and need for cognitive closure were examined is 18-25. Individuals out of this age group is excluded. Thirdly, all of the sample group consists of the university students. Those who are not university students are out of the scope of the study. It is recommended that the further studies on the subject should have a scope which eliminates these limitations.

Individuals who will migrate to other countries to study or work should have an orientation training even for a short period regarding the thinking styles and decision making styles of the society they will visit. The number of young people who visit other cultures for education purposes increases rapidly. There should be courses in the preparatory class or the first year of the multicultural education institutions which include learning a new culture and cultural differences.

An education program to be drafted by UNESCO aiming to increase intercultural knowledge, tolerance, rapprochement and empathy should be included in the curriculum of countries. Having experimental model rather than descriptive model in the studies to be conducted on intercultural thinking and decision making will contribute to obtaining results with high consistency in such studies. In this scope, there should be more studies which involve direct observation of the thinking styles and decision making styles by introducing people from different cultures into certain problem conditions.

\section{Conclusion}

A certain thinking style or decision making style is not better or worse than the other. There are even circumstances and positions where individuals with high need for cognitive closure are advantageous. What matters is that people from different cultures who need to live together or have relation with each other should have knowledge about their thinking styles and decision making styles of each other. This knowledge will increase the cooperation and efficiency between cultures. At the same time, this knowledge will play a role in reducing and solving conflicts. The study found that the Turkish, Uzbek and Kyrgyz students have significant differences in thinking, decision making and cognitive closure. Apart from eliminating, these differences should be accepted as an asset and ways should be sought to benefit from this asset in political, economic and cultural areas.

\section{References}

Aljojo, N., 2017. Differences in styles of thinkingin light of sternberg's theory': A case study of different educational levels in Saudi Arabia. Journal of Technology and Science Education, 7(3): 333-346. View at Google Scholar | View at Publisher

Balkis, M. and G.B. Isiker, 2005. The relationship between thinking styles and personality types. Social Behavior and Personality: An International Journal, 33(3): 283-294. View at Google Scholar | View at Publisher

Bernardo, A.B., L.F. Zhang and C.M. Callueng, 2002. Thinking styles and academic achievement among Filipino students. Journal of Genetic Psychology, 163(2): 149-163. View at Google Scholar | View at Publisher 
Buluş, M., 2006. Assessment of thinking styles inventory, academic achievement and student teachers' characteristics. Education and Science, 31(139): 35-48. View at Google Scholar

Byrnes, J.P., 2002. The development of decision-making. Journal of Adolescent Health, 31(6): 208-2 15. View at Google Scholar

Cheng, H., H.L. Andrade and Z. Yan, 2011. A cross-cultural study of learning behaviours in the classroom: From a thinking style perspective. Educational Psychology, 31(7): 825-841. View at Google Scholar |View at Publisher

Cherian, J., 2014. American and Chines thinking styles: Attitude effects on holistic and attribute. Organization And Markets in Emerging Economies, 5(1 (9)): 74-89.

Dabić, M., D. Tipurić and N. Podrug, 2015. Cultural differences affecting decision-making style: A comparative study between four countries. Journal of Business Economics and Management, 16(2): 275-289. View at Google Scholar | View at Publisher

Emamipour, S. and H.S. Esfandabad, 2013. Developmental study of thinking styles in Iranian students university. Procedia-Social and Behavioral Sciences, 84: 1736-1739. View at Google Scholar | View at Publisher

Fan, J., L. Zhang and C. Chen, 2018. Thinking styles: Distinct from personality? Personality and Individual Differences, 125(15): 50-55. View at Google Scholar | View at Publisher

at Google Scholar | View at Publisher
Fer, S., 2005. Validity and reliability study of the thinking styles inventory. Educational Sciences Theory \& Practice, 5(1): 433-461. View at Google Scholar

Garcia, C.F. and E. Hughes, 2000. Learning and thinking styles: An analysis of their interrelationship and influence on academic achievement. Educational Psychology, 20(4): 413-430. View at Google Scholar $\mid$ View at Publisher

Guess, C., 2004. Decision making in individualistic and collectivistic cultures. Online Readings in Psychology and Culture, 4(1): 3-18. View at Google Scholar | View at Publisher

Güss, C.D. and D. Dörner, 2011. Cultural differences in dynamic decision-making strategies in a non-linear, time-delayed task. Cognitive Systems Research, 12(3-4): 365-376. View at Google Scholar | View at Publisher

Hiel, A.V. and I. Mervielde, 2005. Authoritarianism and social dominance orientation: Relationships with various forms of racism. Journal of Applied Social Psychology, 35(11): 2323-2344. View at Google Scholar $\mid$ View at Publisher

Jun, H., 2016. Thinking styles and intercultural competencies. Journal of Intercultural Management, 8(4): 89-1 16. View at Google Scholar $\mid$ View at Publisher

Kim, M., 2011. The relationship between thinking style differences and career choices for high-achieving students. Roeper Review, 33(4): 252-262. View at Google Scholar|View at Publisher

Kossowska, M., A. Van Hiel, W.Y. Chun and A.W. Kruglanski, 2002. The need for cognitive closure scale: Structure, cross-cultural invariance, and comparison of mean ratings between European-American and East Asian samples. Psychologica Belgica, 42(4): 267-286. View at Google Scholar

Kruglanski, A.W. and D.M. Webster, 1996. Motivated closing of the mind:" Seizing" and" freezing. Psychological Review, 103(2): 263-283. View at Google Scholar | View at Publisher

Lee, L.N., 2017. Cross-cultural differences in thinking: Some thoughts on psychological paradigms. Rationality Academic Press. pp: 61-73.

Liliweri, A., 2017. An analysis on the relationship of thinking and learning styles with communication style. International Journal of School and Cognitive Psychology, 4: 192. View at Publisher

Mannetti, L., A. Pierro, A. Kruglanski, T. Taris and P. Bezinovic, 2002. A cross-cultural study of the need for cognitive closure scale: Comparing its structure in Croatia, Italy, USA and The Netherlands. British Journal of Social Psychology, 41(1): 139-156. View at Google Scholar | View at Publisher

Mau, W.-C., 2000. Cultural differences in career decision-making styles and self-efficacy. Journal of Vocational Behavior, 57(3): 365-378. View at Google Scholar | View at Publisher

Müller, R., K. Spang and S. Özcan, 2008. Cultural differences in decision-making among project teams: Examples from Swedish and German project teams. Paper Presented at PMI Research Conference: Defining the Future of Project Management, Warsaw, Poland. Newtown Square, PA: Project Management Institute.

Nikčević, A., C. Marino, G. Caselli and M. Spada, 2017. The importance of thinking styles in predicting binge eating. Eating Behaviors, 26: 40-44. View at Google Scholar $\mid$ View at Publisher

Oliveira, S. and R.E. Nisbett, 2017. Culture changes how we think about thinking: From "human inference" to "geography of thought. Perspectives on Psychological Science, 12(5): 782 -790. View at Google Scholar | View at Publisher

Qi, X., 2017. Why does traditional China education system place less importance on critical thinking than western system? An evaluation of how to implement critical thinking in Chinese education effectively. Advances in Higher Education, 1(1): 39-47. View at Google Scholar

Roets, A. and V.A. Hiel, 2011. Item selection and validation of a brief, 15-item version of the need for closure scale. Personality and Individual Differences, 50(1): 90-94. View at Google Scholar $\mid$ View at Publisher

Scott, S.G. and R.A. Bruce, 1995. Decision-making style: The development and assessment of a new measure. Educational and Psychological Measurement, 55(5): 818-831. View at Google Scholar | View at Publisher

Spicer, D.P. and E. Sadler-Smith, 2005. An examination of the general decision making style questionnaire in two UK samples. Journal of Managerial Psychology, 20(2): 137-149. View at Google Scholar $\mid$ View at Publisher

Sternberg, R. and C. Cilliers, 2001. Thinking styles: Implications for optimising learning and teaching in university education. South African Journal of Higher Education, 15(1): 13-24. View at Google Scholar | View at Publisher

Sternberg, R.J., 2001. Teaching psychology students that creativity is a decision. General Psychologist, 36(1): 8-11.

Sternberg, R.J. and R.K. Wagner, 1992. Thinking styles inventory. Unpublished Test, Yale University, New Havan, CT.

Taşdelen, A., 2002. Decision-making styles for prospective teachers according to different psycho-social variables. Ph.D. Thesis. Dokuz Eylül University Educational Sciences Institute, Izmir.

Tipandjan, A., 2010. Cross-cultural study on decision making of german and indian university students. Presented by the Faculty of Humanities and Social Sciences of Chemnitz University of Technology.

Todor, I., 2014. Need for closure and cognitive inhibition of unwanted or irrelevant information. Procedia-Social and Behavioral Sciences, 141: 712-717. View at Google Scholar | View at Publisher

Torrance, E.P. and S. Sato, 1979. Differences in Japanese and United States styles of thinking. Creative Child \& Adult Quarterly, 4(3): 145151. View at Google Scholar

Varnum, M.E., I. Grossmann, S. Kitayama and R.E. Nisbett, 2010. The origin of cultural differences in cognition: The social orientation hypothesis. Current Directions in Psychological Science, 19(1): 9-13. View at Google Scholar

Yaakobi, E., 2017. Thinking styles and performance. Journal Clinical Psychiatry and Cognitive Psychology, 1(1): 7-8. View at Google Scholar

Yeonyeob, L., 2011. Decision-making uncertainty, need for cognitive closure, and supply chain performance. Diss. Cleveland State University.

Yuan, W., L.-F. Zhang and M. Fu, 2017. Thinking styles and academic stress coping among Chinese secondary school students. Educational Psychology, 37(8): 1015-1025. View at Google Scholar $\mid$ View at Publisher

Zhang, L.-F., 2002. Thinking styles and modes of thinking: Implications for education and research. The Journal of Psychology, 136(3): 245261. View at Google Scholar | View at Publisher

Zhang, L.-f. and J. Huang, 2001. Thinking styles and the five-factor model of personality. European Journal of Personality, 15(6): 465-476. View at Google Scholar | View at Publisher 